\title{
PERFORMANCE EVALUATION OF PROPERTY AND REAL ESTATE COMPANIES LISTED ON INDONESIA STOCK EXCHANGE USING DATA ENVELOPMENT ANALYSIS
}

\author{
Tessa V. Soetanto \\ Liem Pei Fun \\ Faculty of Economics, Petra Christian University \\ Siwalankerto 121-131, Surabaya 60236 \\ Email: tessa@petra.ac.id
}

\begin{abstract}
This paper aimed to evaluate perfomance of property and real estate companies listed in Indonesia Stock Exchange using the DEA method. Samples were 23 companies listed from 2009-2012. Results showed that some companies are relatively efficient each year. However, only one company consistently had technical efficiency equal to 1 . The main cause of inefficiency from 2009-2011 was scale inefficiency while inefficiency happened in 2012 was pure technical inefficiency. Overall the companies operate efficiently under constant returns to scale is showing an increase from $17.39 \%-39.13 \%$.
\end{abstract}

Keywords: Company Performance, Technical Efficiency, Property and Real Estate, DEA

\begin{abstract}
Abstrak
Penelitian ini bertujuan untuk mengevaluasi kinerja perusahaan properti dan real estat yang terdaftar di BEI dengan menggunakan metode DEA. Sampel sebanyak 23 perusahaan yang terdaftar di BEI dengan periode 2009-2012. Hasil menunjukkan bahwa beberapa perusahaan relatif efisien setiap tahunnya, namun ada satu perusahaan yang secara konsisten memiliki technical efficiency sama dengan satu selama periode 2009-2012. Penyebab utama ketidakefisienan selama periode 2009-2011 adalah scale inefficiency sedangkan tahun 2012 adalah pure technical inefficiency. Persentase perusahaan yang mengalami peningkatan efisiensi secara constant return to scale dari 17,39\%-39,13\%.
\end{abstract}

Kata Kunci: Kinerja Perusahaan, Technical Efficiency, Properti dan Real Estat, DEA

\section{INTRODUCTION}

The property market in Indonesia has experienced attractive growth in the past few years. Compared to other sector indexes in the Indonesian stock market, the property stock index has benefit from higher growth during 2012. The Indonesia property sector index grew profoundly, exceeding the growth in the Indonesia stock market index which is known as Indeks Harga Saham Gabungan (IHSG). On 12 October 2012, IHSG reached 4,331 which showed increase of 489.4 points or increased $12.8 \%$ compared to 2011 while on the same date, property stock index increased $34.37 \%$ (Saham Properti Incaran Investor, 2012).

Thus far, the escalation of the property sector in Indonesia is driven by positive performance in property markets. High demand of property caused by an increase in the number of middle class people combined with rising price in property offer potential op- portunities for developers. During 2012, many companies from the property sector listed on the Indonesia Stock Exchange obtain high revenue and net income growth. For instance, PT Ciputra Property Tbk reported revenue of Rp826 billion in 2012 or an increase of around 88\% compared to 2011 (Ciputra Property Tbk, 2012) while PT Pakuwon Jati Tbk attained revenue of $\mathrm{Rp} 2.165$ trillion in 2012 or an increase of approximately $46 \%$ compared to the previous year (Pakuwon Jati Tbk, 2012). Other developers, PT Alam Sutera Realty Tbk booked net income of Rp1.216 trillion during 2012 or an increase of $102 \%$ compared to 2011 (Alam Sutera Realty Tbk, 2012) while PT Lippo Karawaci Tbk reported net income of Rp2.483 trillion or an increase of $205 \%$ compared to the previous year (Lippo Karawaci Tbk, 2012).

Although many publicly listed companies in the property and real estate sector encountered significant growth in revenue and net income, not all companies 
in that sector enjoyed the same experience. For example, during 2012, PT Bakrieland Development Tbk experienced a loss of Rp1.269 trillion (Bakrieland Tbk, 2012). It shows that growth in the property sectors are not automatically shared by all companies in that sector. How well companies managed their assets to maximize profit will determine their performance. Investors need to allocate the money in the companies that perform well to ensure they receive added value from their investments. Therefore, evaluating companies' performance is essential for investors.

Ratio analysis is a commonly used method to evaluate firm performance. However, many studies point out that traditional ratio analysis is insufficient to evaluate firm performance and suggest Data Envelope Analysis (DEA) as an augmented method for the analysis of firm performance (Feroz et al., 2003; Horta et al., 2010, Gumus \& Celikkol, 2011). Feroz et al. (2003) underline that although ratios are easy to compute, the major drawback with traditional ratio analysis is that their interpretation could be problematic in assessing overall firm performance, particularly when two or more ratios provide conflicting signals. They show that Data Envelopment Analysis (DEA) can improve traditional ratio analysis and conclude that DEA efficiency scores have incremental information content above the information generated by ratios. In line with that, research done by Gumus \& Celikkol (2011) using nonfinancial firms listed on the Istanbul Stock Exchange for the period between 2005 and 2008 indicates that DEA and ratio analysis are complementary in terms of liquidity and profitability. Furthermore, Horta et al. (2010) state "one of the advantages of DEA method is to allow aggregating multiple dimensions of company activity, evaluated by several key performance indicators (KPIs), into a single summary measure of performance." Therefore, this research employs DEA method to analyze firm performance.

To the best knowledge of authors, there is no research previously has ever measured the performance of property companies listed on the Indonesian Stock Exchange using DEA method. Hence, this research can potentially contribute to the literature and provide valuable information on the technical efficiency of property companies listed in Indonesia Stock Exchange in particular and property sector in Indonesia in general.

\section{LITERATURE REVIEW}

Data Envelopment Analysis (DEA) is commonly used as a measure to examine the performance of the organizations in various of industry such as banks (Pasiouras et al., 2007; Saad \& Moussawi, 2009; Su- zuki \& Sastrosuwito, 2011; Soetanto \& Ricky, 2011), shipping industry (Lin et al., 2005), investment companies (Zohdi et al., 2012; Zhao et al., 2011), and hospitality and tourism (Chen, 2009; Sigala, 2004).

Yu \& Han (2012) used DEA to evaluate the technical efficiency of 26 publicly listed companies on the Taiwan Stock Exchange in 2010. DEACharnes, Cooper, Rhodes (CCR) model was used to find the technical of efficiency of each firm within the year. The input variables were the annual total fixed assets, operating cost, and the number of employees while the output variables were annual total sales and on operating income. It was found that score of technical efficiency ranged from $0.61-1.00$ and only six out of 26 semiconductor companies listed on Taiwan Stock Exchange were relative efficient.

Memon \& Tahir (2012) measured and evaluated the relative efficiency of 49 manufacturing companies in Pakistan from 2008-2010 using DEA and categorized them based on the DEA efficiency and profitability index (ROA) to form the performance matrix. It employed both Charnes, Cooper, Rhodes (CCR), and Banker, Charnes, Cooper (BCC) models of DEA to find the overall technical efficiency (OTE), pure technical efficiency (PTE) and scale efficiency (SE) and found that eight companies were considered technically efficient while the source of inefficiency is pure technical efficiency rather than scale inefficiency. Through the performance matrix, there were 13 out of 49 companies in the superstart quadrant characterized by high efficiency and high profitability. Further, there were 20 companies in the problemchild quadrant characterized by low efficiency and low profitability.

Zheng et al. (2011) measured performance and efficiency of the listed real estate companies in China using three types of DEA models which are CCR, BCC and Super efficiency. Empirical analysis was conducted on 94 listed real estate companies in China stock exchanges in 2009. The input variables were registered capital, asset value, employee number and operation cost, while the output variables were revenue and profit. There were three efficiencies calculated namely the overall technical efficiency (OTE), pure technical efficiency (PTE) and scale efficiency (SE). The result showed that the average of OTE, PTE and SE of the listed real estate companies were $0.78,0.84$, and 0.92 respectively and about $69 \%$ of the inefficient companies were categorized as having increasing returns to scale.

Nanka-Bruce (2006) investigated the technical efficiency in the real estate sector of Spain for the period 1998-2003 and related the findings to the ownership structure of the firms using DEA. There were 
530 firms being analyzed and the variables being used for inputs were fixed assets, material costs, employee costs and other costs while the output variable was operating turnover. The analysis was adopting inputoriented radial DEA under variable returns to scale (VRS) technology to measure technical efficiency. It was revealed that firms were only $69 \%$ efficient in their productive efficiency and experienced a downward trend in technical efficiency from 1998 to 2002 attributable to the increasing demand for new property. The most inefficient firms were stateowned compared with industrial companies as the ultimate owners.

To date, there has been relatively limited research conducted in evaluating the efficiency of property and real estate industry listed publicly in Indonesia. Most of the research being conducted to analyze the performance of the companies has been based on financial ratios and price of the stock as in Saskia (2013) and Amalia (2012). Other research by Septyo (2013) was evaluating the performance of property and real estate companies listed on the Indonesia Stock Exchange from 2009-2011 using Public-Value Added Intellectual Coefficients (VAIC) while Nugroho (2012) used Economic Value Added to measure the financial performance in property industry from 2004-2010. To the best knowledge of the authors, no research paper has ever measured the performance evaluation of property and real estate sector listed in Indonesian Stock Exchange using DEA.

\section{RESEARCH METHOD}

The nonparametric method of Data Envelopment Analysis (DEA), initially introduced by Charnes et al. (1978), to evaluate the efficiency of decisionmaking units (DMU) particularly in terms of efficiency. The DEA model forms a relative efficiency score by converting the multiple-input or multiple-output variables to a single measure of performance for each DMU (Horta et al., 2010). This happens by establishing an empirically based "bestpractice" or efficient frontier as a result of classifying a set of efficient DMUs which lies on the frontier and inefficient DMUs which do not lie on the frontier (Wagner \& Shimshak, 2007).

There are several of advantages of DEA compared to other methods such as Stochastic Frontier Analysis (SFA), Thick Frontier Approach, Distribution Free Approach (DFA) and etc. It does not have any assumption of frontier functional form, considers various inputs and outputs simultaneously, no prior specific behavioural assumptions of relationship needed and able to have different measurement units between inputs and outputs (Cooper et al., 2004; Charnes et al., 1978). Another advantages of DEA is no assumption related to the distribution of efficiencies and no prior information related to prices (Mohammadi \& Ranaei, 2011).

There are two versions of the DEA model based on its features, namely constant return to scale (CRS) or CCR (Charnes et al., 1978) and variable returns to scale (VRS) or BCC (Banker et al., 1984). Charnes et al. (1978) used a mathematical programming model to identify the efficiency frontier based on the concept of Pareto optimality when multiple measures are applied. The ratio of outputs to inputs is used to measure the relative efficiency of the $\mathrm{DMU}_{\mathrm{j}}=\mathrm{DMU}_{0}$ to be evaluated relative to the ratios of all of the $j=1,2$, .., $n$ DMU. This basic DEA model implies the assumption of Constant Returns to Scale (CRS). Using Charnes-Cooper transformation and dual formulation under CRS, then:

$\theta^{*}=$ Minimum $\theta$

Subject to $\sum_{j=1}^{n} \lambda_{j} x_{i j}-\theta x_{i 0} \leq 0 \quad i=1, \ldots, m$

$\sum_{j=1}^{n} \lambda_{j} y_{r j}-y_{j 0} \geq 0 \quad r=1, \ldots, s \quad \lambda \mathrm{j} \geq 0 \forall j$

The optimal solution, $\theta^{*}$, yields an efficiency score for a certain DMU. The process is repeated for each $\mathrm{DMU}_{\mathrm{j}}$. DMUs for which $\theta^{*}<1$ are inefficient, while DMUs for which $\theta^{*}=1$ are boundary points or efficient. This model is sometimes referred to as the "Farrell model" (Cooper et al., 2004). In the CRS version, it is assumed that an increase in the amount of inputs would directly be proportional to an increase in the amount of outputs. During the process, however, there may be increasing or decreasing returns to scale, particularly for an inefficient DMU, which may occur from the different returns to scale of the operation (Boussofiane et al., 1991).

The efficiency measure derived from the model reflects the technical efficiency (TE). Technical efficiency (TE) refers to ability to produce the maximum outputs at a given level of inputs (output-oriented), or ability to use the minimum level of inputs at a given level of outputs (input-oriented). The envelopment surface resulting from the CCR model has the shape of a convex cone and the efficient DMUs would lie on top of the structure, while the inefficient ones would be below the cone.

Due to imperfect competition or constraints in finance, not all companies are able to operate at the optimal scale. In that condition, Banker et al. (1984) suggested the use of Variable Return to Scale (VRS), denoted as BCC hereafter, that allows the calculation of efficiency leads to decomposition of technical efficiency into scale (SE) and pure technical efficiency (PTE) components. The BCC model is (1) toge- 
ther with additional constraint that captures returns to scale characteristics

$$
\sum_{j=1}^{n} \lambda_{j}
$$

Then, the efficiency estimates obtained in the BCC model is net of the contribution of scale economies and therefore is referred to as 'pure' technical efficiency and also as the managerial efficiency. In the VRS version, the amount of outputs is considered to increase more or less than proportionally than the increase in the inputs.

A DEA model can be constructed either to minimize inputs or maximize outputs. An input orientation aims at reducing the input amounts as much as possible while keeping at least the present output levels, while an output orientation points toward maximizing output levels without increasing use of inputs (Cooper et al., 2004). The input and output measurements are always the same in the CCR model, but frequently differ in the BCC model. First, one model can be solved and be given either interpretation in CCR model while in BCC model, only the input interpretation be given and another solution must be made on the output to get the interpretation of it. Another difference between those two models is the efficiency score resulting from CCR Model is the same by scalar transformations of all data for a given DMU while not the same thing happens in BCC Model (Martic et al., 2009).

Both CCR and BCC models will result of efficiency scores between 0.0 and 1.0. It implies that DMUs are either on the efficiency frontier or below it. A company is efficient if it has an efficiency score of 1.0 or can be said that it lies on the efficient frontier, and otherwise if it has an efficiency score below 1.0.

\section{Data and Variables}

The data used in the analysis were collected from Annual Reports of company websites and the Indonesian Stock Exchange database. This research used property and real estate companies listed on the Indonesian Stock Exchange from the period of 2009 2012. Companies which experienced delisting during the period and those that lack data on selected variables for at least one year are eliminated, leading to 23 companies for further analysis.

A crucial phase in DEA measurement is classification of the input or output variables related to the units being measured (Boussofiane et al., 1991). DEA calculates efficiency directly from the input or output data, then the results will depend on the input or output adoption for analysis and the homogeneity of the DMUs to be assessed (Boussofiane et al., 1991). As stated by Sigala (2004), one primary drawback of DEA model is the difficulty in defining and classifying the measurement of inputs or outputs.

Based on previous research (Zheng et al., 2011; Nanka-Bruce, 2006; Yu \& Han, 2012; Memon \& Tahir, 2012) and considering the condition of the property and real estate companies in Indonesia, then the input variables are fixed assets, operating expense, inventories and land for development (consists of land that is currently being developed, land that is not yet being developed, asset real estate and investment property). Preceding articles use revenues and net income as output (Zheng et al., 2011; Memon \& Tahir, 2012; Yu \& Han, 2012). However, since net income is subject to revenue, there is potential of endogeneity bias in DEA as pointed out by Orme \& Smith (1996). Moreover, in the presence of relatively small number of DMUs, having more output than are necessary will lead to loss of discriminatory power of DEA which result in higher overall efficiency score (Hughes \& Yaisawarng, 2004). Therefore, this research only use one output which is net income.

According to Chen (2009), some guidelines have been proposed by previous research to limit the number of variables relative to the number of DMUs to achieve a rational level of discernments. Dyson et al. (2001) as cited by Chen (2009), stated that the number of DMUs should be at least two times of the number of inputs and outputs (i.e. $n \geq 2 m s$ ). This research use 3 input variables $(m=3)$ and 2 output variables $(s=2)$ hence the number of DMUs should be more than $12(2 \times 3 \times 2)$. The guideline is fulfilled since there are 23 property and real estate companies being analyzed in this research.

\section{RESULTS AND ANALYSIS}

Table 1 shows descriptive statistics for inputs and outputs variable of 23 publicly listed property and real estate companies for 4 year-period (20092012). The values are given in million Rupiah. Table 1 displays that for input variables, the highest operating expenses and inventories \& land for development happened in 2012 while the highest fixed assets is in 2011. During 2009 to 2012, the highest operating expenses amount is Rp1,343,939 million or Rp1.34 trillion spent by PT Lippo Karawaci Tbk in 2012 while the highest inventories and land for development value is Rp11.886 trillion, owned by PT Lippo Karawaci Tbk. PT Ciputra Development Tbk has highest fixed asset during the period of investigation. For output variable, mean of the net income is increasing from 2009 to 2012. Highest reported net in- 
Table 1. Descriptive Statistics for the Data

\begin{tabular}{|c|c|c|c|c|c|}
\hline & Factors & Min & Max & Mean & Std. Dev. \\
\hline \multicolumn{6}{|c|}{ Year 2009} \\
\hline \multirow[t]{3}{*}{ Inputs } & Operating Expense (Million IDR) & 4,096 & 705,861 & 171,239 & 189,219 \\
\hline & Fixed Assets (Million IDR) & 729 & $1,559,360$ & 432,230 & 534,168 \\
\hline & Inventories \& Land for Development (Million IDR) & 35,208 & $7,299,603$ & $1,963,994$ & $1,871,100$ \\
\hline Output & Net Income (Million IDR) & 2,355 & 388,053 & 101,943 & 117,447 \\
\hline \multicolumn{6}{|c|}{ Year 2010} \\
\hline \multirow[t]{3}{*}{ Inputs } & Operating Expense (Million IDR) & 6,705 & 802,411 & 198,053 & 219,466 \\
\hline & Fixed Assets (Million IDR) & 356 & $2,012,890$ & 473,280 & 590,593 \\
\hline & Inventories \& Land for Development (Million IDR) & 84,770 & $8,558,284$ & $2,192,887$ & $2,094,820$ \\
\hline Output & Net Income (Million IDR) & 8,401 & 525,346 & 145,936 & 146,810 \\
\hline \multicolumn{6}{|c|}{ Year 2011} \\
\hline \multirow[t]{3}{*}{ Inputs } & Operating Expense (Million IDR) & 1,019 & 968,324 & 241,102 & 265,811 \\
\hline & Fixed Assets (Million IDR) & 671 & $2,395,684$ & 634,063 & 739,434 \\
\hline & Inventories \& Land for Development (Million IDR) & 93,090 & $9,159,336$ & $2,687,242$ & $2,383,928$ \\
\hline Output & Net Income (Million IDR) & 5,901 & $1,012,034$ & 249,861 & 268,289 \\
\hline \multicolumn{6}{|c|}{ Year 2012} \\
\hline \multirow[t]{3}{*}{ Inputs } & Operating Expense (Million IDR) & 9,176 & $1,343,939$ & 281,370 & 336,928 \\
\hline & Fixed Assets (Million IDR) & 694 & $2,222,377$ & 570,806 & 648,231 \\
\hline & Inventories \& Land for Development (Million IDR) & 103,038 & $11,886,493$ & $3,590,021$ & $3,337,621$ \\
\hline Output & Net Income (Million IDR) & 4,488 & $2,482,548$ & 455,816 & 595,930 \\
\hline
\end{tabular}

come is $\mathrm{Rp} 2,482,548$ million or $\mathrm{Rp} 2.48$ trillion is earned by PT Lippo Karawaci Tbk in 2012.

After input and output variables data were collected, they were processed using DEA Frontier software developed by Zhu (2000; 2009). The first stage is running the data based on the CCR model with the orientation of minimizing inputs to get technical efficiency (TE). The technical efficiency of 23 publicly listed property and real estate companies per year during 2009-2012 are shown in Table 2.

From Table 2, it can be seen that each year from 2009 until 2012, some companies have technical efficiency equal 1.0 which means that those companies are efficient in using their inputs (operating expenses, fixed assets, inventories \& land for development) to produce outputs (revenues and net income) for that particular year. However, companies having technical efficiency equal to 1.0 are not the same each year. In 2009, there are four companies that have technical efficiency equal 1.0 which are PT Alam Sutera Realty Tbk, PT Bekasi Asri Pemula Tbk, PT Cowell Development Tbk, and PT Jaya Real Property Tbk. In 2010, there are six companies which have technical efficiency equal 1.0. They are PT Alam Sutera Realty Tbk, PT Bekasi Asri Pemula Tbk, PT Ciputra Property Tbk, PT Ciputra Surya Tbk, PT Indonesia Prima
Property Tbk, and PT Pakuwon Jati Tbk. In 2011, there are six companies having technical efficiency equal 1.0 which are PT Alam Sutera Realty Tbk, PT Cowell Development Tbk, PT Gowa Makassar Tourism Development Tbk, PT Indonesia Prima Property Tbk, PT Jaya Real Property Tbk, and PT Lippo Cikarang Tbk. In 2012, nine companies are having technical efficiency equal 1.0. Those companies are PT Alam Sutera Realty Tbk, PT Cowell Development Tbk, PT Danayasa Arthatama Tbk, PT Gowa Makassar Tourism Development Tbk, PT Jaya Real Property Tbk, PT Lippo Cikarang Tbk, PT Lippo Karawaci Tbk, PT Pakuwon Jati Tbk, and PT Summarecon Agung Tbk. From the table, it also can be seen that there is only one publicly listed company that consistently had technical efficiency equal to 1.0 during 2009 to 2012, which is PT Alam Sutera Realty Tbk.

Following the technical efficiency result of 23 publicly listed property and real estate companies, the average score of technical efficiency during the period of study is also calculated, as shown in Table 3. Afterward, the BCC model can be proceed with orientation of minimizing inputs to obtain pure technical efficiency (PTE). Then scale efficiency ( $S E$ ) can be calculated as $S E=T E / P T E$. The result of PTE and SE can be seen in Table 4. 
Table 2. Technical Efficiency of 23 Publicly Listed Property \& Real Estate Companies

\begin{tabular}{lcccc}
\hline \multicolumn{1}{c}{ DMU Name } & \multicolumn{3}{c}{ Technical Efficiency } \\
\cline { 2 - 4 } & Year 2009 & Year 2010 & Year 2011 & Year 2012 \\
\hline Alam Sutra Realty & 1.00000 & 1.00000 & 1.00000 & 1.00000 \\
Bekasi Asri Pemula & 1.00000 & 1.00000 & 0.79529 & 0.61387 \\
Bumi Serpong Damai & 0.51946 & 0.54463 & 0.78449 & 0.77190 \\
Ciputra Development & 0.37591 & 0.57658 & 0.58347 & 0.68147 \\
Ciputra Property & 0.38848 & 1.00000 & 0.65921 & 0.46615 \\
Ciputra Surya & 0.35201 & 1.00000 & 0.59496 & 0.70940 \\
Cowell Development & 1.00000 & 0.97509 & 1.00000 & 1.00000 \\
Danayasa Arthatama & 0.85226 & 0.54369 & 0.37935 & 1.00000 \\
Duta Anggada Realty & 0.65491 & 0.76883 & 0.30309 & 0.92657 \\
Gowa Makassar Tourism & 0.65890 & 0.65420 & 1.00000 & 1.00000 \\
Indonesia Prima Property & 0.49609 & 1.00000 & 1.00000 & 0.94474 \\
Intiland Development & 0.42025 & 0.95843 & 0.48723 & 0.54987 \\
Jakarta Inter Hotel & 0.80389 & 0.60827 & 0.42524 & 0.46213 \\
Jaya Real Property & 1.00000 & 0.91717 & 1.00000 & 1.00000 \\
Kawasan Jababeka & 0.28737 & 0.51809 & 0.63351 & 0.64749 \\
Lamicitra Nusantara & 0.39968 & 0.47501 & 0.20067 & 0.19089 \\
Lippo Cikarang & 0.72974 & 0.68758 & 1.00000 & 1.00000 \\
Lippo Karawaci & 0.46460 & 0.52744 & 0.70364 & 1.00000 \\
Modernland & 0.45000 & 0.49516 & 0.40790 & 0.48010 \\
Pakuwon Jati & 0.75137 & 1.00000 & 0.90173 & 1.00000 \\
Perdana Gapuraprima & 0.42855 & 0.46624 & 0.61504 & 0.63498 \\
Sentul City & 0.33248 & 0.68826 & 0.47757 & 0.59962 \\
Summarecon Agung & 0.51564 & 0.64319 & 0.70468 & 1.00000 \\
\hline
\end{tabular}

Table 3. DEA Result: Technical Efficiency $(T E)$

\begin{tabular}{ccccc}
\hline Year & Mean & Min & Max & St. Dev \\
\hline 2009 & 0.6035 & 0.2874 & 1 & 0.2416 \\
2010 & 0.7412 & 0.4662 & 1 & 0.2114 \\
2011 & 0.6792 & 0.2007 & 1 & 0.2518 \\
2012 & 0.7687 & 0.1909 & 1 & 0.2416 \\
\hline
\end{tabular}

Table 4. DEA Result: Pure Technical Efficiency (PTE) and Scale Efficiency $(S E)$

\begin{tabular}{|c|c|c|c|c|c|c|c|c|}
\hline \multirow[t]{2}{*}{ Year } & \multicolumn{4}{|c|}{$\begin{array}{l}\text { Pure Technical Efficiency } \\
(P T E)\end{array}$} & \multicolumn{4}{|c|}{ Scale Efficiency $(S E)$} \\
\hline & Mean & Min & Max & St. Dev & Mean & Min & $\mathbf{M}$ & \\
\hline 200 & 08038 & 0.3931 & 7 & & 0.7478 & 04223 & 1 & \\
\hline 201 & & & 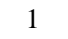 & & & & 1 & \\
\hline 2011 & 0.7925 & 0.3195 & 1 & 0.2 & 0.6792 & 0.2007 & 1 & 0.2518 \\
\hline 2012 & 0.8410 & 0.4714 & 1 & 0.1969 & 0.9178 & 0.2088 & 1 & 0.1829 \\
\hline
\end{tabular}

According to the CCR-DEA model, the average technical efficiency of property and real estate companies in Indonesia as shown in Table 3 is experiencing fluctuation starting from $60.35 \%$ to $74.12 \%$ from 2009 to 2010 and in 2011 is declining to $67.92 \%$ before it is improving to $76.87 \%$ in 2012 . It indicates that the companies could further reduce their factor of production by $39.65 \%$ in 2009 to $23.13 \%$ in 2012 by maintaining the same output level. Table 3 also shows that the minimum technical efficiency keeps decreasing from year to year, except from 2009 to 2010. However in every period of analysis, there are some companies that can achieve technical efficiency as shown by the maximum score equal to 1.0.

Table 4 exhibits the decomposition of technical efficiency into pure technical efficiency and scale efficiency from the year 2009-2011. From Table 4, it can be seen that the average score of pure technical efficiency outweighs the average score of scale efficiency in determining property and real estate companies technical efficiency. The results imply that during these years, the companies in property and real estate sector has been more efficient in controlling their operating costs rather than operating at an optimal scale of operations.

On the other hand, pure technical inefficiency seem to dominate during 2012 compared to scale inefficiency, suggesting that property and real estate sector has been relatively less managerially efficient in controlling their costs and operating at an optimal scale of operations. As in 2012, there is increasing demand of residential houses and apartments as people were more positive about the Indonesian economic circumstances and mortgage loans were more affordable, which was $10.62 \%$ in average based on data of Bank Indonesia (Property and Bank, 2012) compared to the previous years which was $14 \%$ (Finesso, 2009). Moreover, it is supported by the fact that the amount of mortgage loan in February 2012 
Table 5. Summary of Overall Efficiency and Return to Scale

\begin{tabular}{lcccccccc}
\hline & \multicolumn{2}{c}{$\mathbf{2 0 0 9}$} & \multicolumn{2}{c}{$\mathbf{2 0 1 0}$} & \multicolumn{2}{c}{$\mathbf{2 0 1 1}$} & \multicolumn{2}{c}{$\mathbf{2 0 1 2}$} \\
\cline { 2 - 9 } & Count & $\%$ & Count & $\%$ & Count & $\%$ & Count & $\%$ \\
\hline Efficient (CRS) & 4 & $17.39 \%$ & 6 & $26.09 \%$ & 6 & $26.09 \%$ & 9 & $39.13 \%$ \\
Inefficient & 19 & $82.61 \%$ & 17 & $73.91 \%$ & 17 & $73.91 \%$ & 14 & $60.87 \%$ \\
CRS & 4 & $17.39 \%$ & 6 & $26.09 \%$ & 6 & $26.09 \%$ & 9 & $39.13 \%$ \\
IRS & 1 & $4.35 \%$ & 0 & $0.00 \%$ & 3 & $13.04 \%$ & 7 & $30.43 \%$ \\
DRS & 18 & $78.26 \%$ & 17 & $73.91 \%$ & 14 & $60.87 \%$ & 7 & $30.43 \%$ \\
\hline
\end{tabular}

was increasing 33\% compared to February 2011 (Property and Bank, 2012).

This research also evaluate the nature of scale efficiencies based on the number of property and real estate companies operating under constant, increasing and decreasing returns to scale. From Table 5, the percentage of companies operating under constant returns to scale is increasing from $17.39 \%$ to $39.13 \%$ during the period of 2009-2012 while the companies that are not efficient are mostly having decreasing returns to scale. The percentage of companies who experience the decreasing returns to scale is $78.26 \%$ in 2009 and decline to $30.43 \%$ in 2012.

\section{CONCLUSION}

The positive and attractive performance of property companies has driven the Indonesian property sector's growth significantly as can be seen by the increasing revenues of some property and real estate companies listed in Indonesian Stock Exchange. However not all companies enjoyed the same condition and evaluating the performance of companies is necessary to know their sustainability. Besides it is helping investors to seek the right choice in doing investment.

This research utilizes DEA to evaluate the performance of property and real estate companies listed on the Indonesian Stock Exchange in the period of 2009-2012 as DEA is a highlyregarded method for evaluating performance which usually consists of multidimensional factors. DEA is converting multiple inputs and multiple outputs into a single measurement of performance which is technical efficiency and further can be decomposed into pure technical efficiency and scale efficiency. The DEA result shows that only PT Alam Sutera Realty Tbk was technically efficient during the period of study. The average score of technical efficiency from all property and real estate companies listed in Indonesian Stock Exchange varies from $60.35 \%$ to $74.12 \%$ (2009-2010), then went down to $67.92 \%$ (2011) and reached $76.87 \%$ in 2012. Meanwhile the cause of inefficiency from the period of 2009-2011 is scale. The inefficiency that happened in the last period of study is pure technical inefficiency, which means companies are not controlling their costs efficiently and are operating at optimal scale of operation as the increasing demand of residential houses and apartments in 2012. Overall the percentage of companies operating under constant returns to scale is increasing from $17.39 \%$ to $39.13 \%$ during 2009-2012.

\section{REFERENCES}

Alam Sutera Realty Tbk. 2012. PT Alam Sutera Realty Tbk and Subsidiaries Consolidated Financial Statements, (http://www.idx.co.id, retrieved April 8, 2013).

Amalia, T. 2012. Pengaruh Kinerja Keuangan Terhadap Harga Saham (Studi pada Perusahaan Properti dan Real Estate yang Terdaftar di Bursa Efek Indonesia Periode 2006-2010). Unpublished Thesis. Jakarta: Universitas Gunadarma.

Bakrieland Tbk. 2012. PT Bakrieland Development Tbk and Subsidiaries Financial Report, (http:// www. idx. co.id, retrieved April 8, 2013).

Banker R. D., Charnes A., \& Cooper W. W. 1984. Some Models for Estimating Technical and Scale Inefficiencies in Data Envelopment Analysis. Management Science, 30(9): 1078-1092.

Boussofiane, A., Dyson, G., \& Thanassoulis, E. 1991. Applied Data Envelopment Analysis. European Journal of Operational Research, 52(1): 1-15.

Charnes, A., Cooper, W. W., \& Rhodes, E. 1978. Measuring the Efficiency of Decision Making Units. European Journal of Operational Research, 2(6): 429-444.

Chen, T. H. 2009. Performance Measurement of an Enterprise and Business Units with an Application to a Taiwanese Hotel Chain. International Journal of Hospitality Management, 28(3): 415422.

Ciputra Property Tbk. 2012. PT Ciputra Property Tbk and Subsidiaries Consolidated Financial Statements, (http://www.idx.co.id, retrieved April 8, 2013). 
Cooper, W. W., Seiford, L. M. \& Zhu, J. 2004. Data Envelopment Analysis: History, Models and Interpretations. Boston: Kluwer Academic Publishers.

Feroz, E. H., Kim, S., \& Raab, R. L. 2003. Financial Statement Analysis: A Data Envelopment Analysis Approach. Journal of the Operational Research Society, 54(1): 48-58.

Finesso, G. M. 2009. Penurunan Suku Bunga KPR Tak Signifikan, (http://tekno. kompas.com, retrieved April 1, 2013).

Gumus, Y. \& Celikkol, H. 2011. Data Envelopment Analysis: An Augmented Method for the Analysis of Firm Performance. International Research Journal of Finance and Economics, 79: 137142.

Horta, I. M., Camanho, A. S., \& Da Costa, J. M. 2010. Performance Assessment of Construction Companies Integrating Key Performance Indicators and Data Envelopment Analysis. Journal of Construction Engineering and Management, 136(5): 581-594.

Hughes, A. \& Yaisawarng, S. 2004. Sensitivity and Dimensionality Tests of DEA Efficiency Scores. European Journal of Operational Research, 154(2): 410-422.

Lin, W. C., Liu, C. F., \& Chu, C. W. 2005. Performance Efficiency Evaluation of the Taiwan's Shipping Industry: An Application of Data Envelopment Analysis. Eastern Asia Society for Transportation Studies, 5: 467-476.

Lippo Karawaci Tbk. 2012. PT. Lippo Karawaci Tbk dan Entitas Anak Laporan Keuangan Konsolidasi, (http://www.idx.co.id, retrieved April 8, 2013).

Martic, M. M, Novakovic, M. S., \& Baggia, A. 2009. Data Envelopment Analysis-Basic Models and Their Utilization. Organizacija, 42(2): 37-43.

Memon, M. A. \& Tahir, I. M. Company Operation Performance Using DEA and Performance Matrix: Evidence from Pakistan. International Journal of Business and Behavioral Science, 2(2): 41-55.

Mohammadi, A. \& Ranaei, H. 2011. The Application of DEA based Malmquist Productivity Index in Organizational Performance Analysis. International Journal of Finance and Economics, 62(6): 67-76.

Nanka-Bruce, D. 2006. Corporate Ownership and Technical Efficiency Analysis in The Spanish Real Estate Sector. Corporate Ownership \& Control, 4(2): 100-113.

Nugroho, B. W. 2012. Analisis Kinerja Keuangan dengan Menggunakan Metode Economic Value
Added pada Industri Properti. Unpublished Thesis. Yogyakarta: Universitas Gajah Mada.

Orme, C. \& Smith, P. 1996. The Potential for Endogeneity Bias in Data Envelopment Analysis. Journal of the Operational Research Society, 47(1): 73-83.

Pakuwon Jati Tbk. 2012. PT. Pakuwon Jati Tbk and Subsidiaries Consolidated Financial Statements, (http://www.idx.co.id, retrieved April 8, 2013).

Pasiouras, F., Sifodaskalakis, E., \& Zopounidis, C. 2007. Estimating and Analysing The Cost Efficiency of Greek Cooperative Banks: An Application of Two Stage Data Envelopment Analysis. University of Bath School of Management Working Paper Series No. 2007/12.

Property and Bank. 2012. Saatnya Belanja Mumpung Bunga Murah, (http://propertynbank.com, retrieved May 9, 2013).

Saad, W. \& Moussawi, C. E. 2009. Evaluating the Productive Efficiency of Lebanese Commercial Banks: Parametric and Non-Parametric Approaches. International Management Review, 5(1): 5-19.

Saham Properti Incaran Investor. 2012. Jawa Pos, 7.

Saskia, F. R. 2013. Analisis Pengaruh Kinerja Perusahaan dan Kinerja Pasar Terhadap Harga Saham pada Perusahaan Real Estate dan Property yang Terdaftar di Bursa Efek Indonesia. Unpublished Thesis. Sumatera Utara: University of Sumatra Utara.

Septyo, L. B. 2013. Modal Intelektual dan Kinerja Perusahaan (Bukti Empiris di Indonesia). Jurnal Ilmiah Universitas Bakrie, 1(2).

Sigala, M. 2004. Using Data Envelopment Analysis for Measuring and Benchmarking Productivity in the Hotel Sector. Journal of Travel and Tourism Marketing, 16 (3): 39-60.

Soetanto, T. V. \& Ricky, S. 2011. Technical Efficiency of Indonesian Commercial Banks: An Application of Two-Stage DEA. Jurnal Manajemen dan Kewirausahaan, 13(2): 108116.

Suzuki, Y. \& Sastrosuwito, S. 2011. Efficiency and Productivity Change of the Indonesian Commercial Banks. IPEDR, 7: 10-14.

Wagner, J. M. \& Shimshak, D. G. 2007. Stepwise Selection of Variables in Data Envelopment Analysis: Procedures and Managerial Perspectives. European Journal of Operational Research, 180(1): 57-67.

Yu, Y. S. \& Han, H. T. 2012. Evaluating Technical Efficiency of Taiwan Public Listed Companies: An Application of Data Envelopment Analysis. Interdisciplinary Journal of Research in Business, 1(12): 16-23. 
Zhao, X., Wang, S., \& Lai, K. K. 2011. Mutual Funds Performance Evaluation Based on Endogenous Benchmarks. Expert Systems with Applications, 38(4): 3663-3670.

Zheng, X., Zhao, K. W., \& Hui, E. C. M. 2011. Efficiency Assessment of Listed Real Estate Companies: An empirical study of China. International Journal of Strategic Property Management, 15(2): 91-104.

Zhu, J., 2000. Multifactor Performance Measure Model with an Application to Fortune 500 companies. European Journal of Operational Research, 123(1):105-124.
2009. Quantitative Models for Performance Evaluation and Benchmarking: Data Envelopment Analysis with Spreadsheets. United States: Springer.

Zohdi, M., Marjani, A. B., Najafabadi, A. M., Alvani, J., \& Dalvand, M. R. 2012. Data Envelopment Analysis (DEA) Based Performance Evaluation System for Investment Companies: Case Study of Tehran Stock Exchange. African Journal of Business Management, 6(16): 5573-5577. 